\title{
Proportional Reasoning: How do the 4th Graders Use Their Intuitive Understanding?
}

\author{
Sylvana Novilia Sumarto ${ }^{1,2,3}$, Frans van Galen ${ }^{4}$, Zulkardi $^{5} \&$ Darmawijoyo ${ }^{5}$ \\ ${ }^{1}$ International Master Program in Mathematiscs Education (IMPoME), Sriwijaya University, Palembang, \\ Indonesia \\ ${ }^{2}$ Faculty of Mathematics and Science, Malang State University, Indonesia \\ ${ }^{3}$ St Albertus Senior High School, Malang, Indonesia \\ ${ }^{4}$ Freudenthal Institute, Utrecht University, the Netherlands \\ ${ }^{5}$ Postgraduate Studies, Sriwijaya University, Indonesia \\ Correspondence: Sylvana Novilia Sumarto, St Albertus Senior High School, Malang, Indonesia. Tel: \\ 628-563-534-799. E-mail: sylvananovilia@yahoo.com
}

Received: June 17, 2013 Accepted: July 18, 2013 Online Published: December 25, 2013

doi:10.5539/ies.v7n1p69 URL: http://dx.doi.org/10.5539/ies.v7n1p69

\begin{abstract}
In Indonesia, the proportion is being taught formally in Grade 5 (10-11 years old). However, the existing learning approach does not support the development of the students' proportional reasoning. The way to teach proportion by giving cross multiplication is not meaningful for the students. They just memorize the procedure without understanding how it works. Within a design research, a learning sequence was developed for Grade 4 students (9-10 years old) in order to develop their proportional reasoning as well as their ability to solve the proportional problem before they learned more formally in Grade 5. The students of Grade 4 might have an intuitive understanding about proportionality and they might be able to deal with the comparison problem. How do they use this intuitive understanding to solve the comparison problem and what kind of difficulties that they faced? These questions were addressed through the analyzing of the students' work on the pretest and the video of students' interview. The result shows that the students' intuitive understanding, in principle, can help them to deal with the comparison problem. The students' experience may lead them to use the concept of proportionality instead of the absolute value in simple comparison problem.
\end{abstract}

Keywords: proportion, proportional reasoning, intuitive understanding, missing value problem, comparison problem

\section{Introduction}

Proportion is one of the concepts in mathematics which can be found everywhere (van Galen, Feijs, Figueiredo, Gravemeijer, Herpen, \& Keijzer, 2008). Even when we cook, we determine the recipe by using the concept of proportion. The recipe to make four pans of pizza is a double recipe of two pans of pizza. If we need two kilograms of rice to make fried rice for 10 people then we need a kilogram of rice for 5 people. It means that the concept of proportion is needed in our life.

Based on the curriculum in Indonesia (Depdiknas, 2006), the proportion was taught in Grade 5 (10-11 years old). According to Zulkardi (2002), most of textbook that used in Indonesia contain mainly the set of rules and algorithm which is already formal and they lack of application which is needed by the students in order to make the concept be real for them. In line with that, in general the teachers teach the proportion by using the notion of algebra and cross multiplication to solve the proportional problem. The students may be able to use that formal procedure to find the answer. However, it is not a guarantee that they understand the insight of the proportionality. As stated by van Galen and van Eerde (2013), the procedures will quickly become vulnerable tricks if they are insufficiently anchored in understanding. Moreover, Lesh, Post and Behr as cited in CPRE, CAMS \& El Paso state the cross multiplication method may not facilitate the development of proportional reasoning; even tend to avoid the proportional reasoning. The students are told to put the numbers on formulas and then compute them. Meanwhile, in Parish (2010), Kilpatrick, Swafford and Findell; Lamon; Lesh, Post and Behr consider the proportional reasoning as a "capstone" of elementary school mathematics. Therefore, we need 
a learning design which can support the students to develop the proportional reasoning as well as the ability to solve the proportional problem. Within a design research, a learning sequence was designed and developed based on the principle of Pendidikan Realistik Matematika Indonesia (PMRI)-the Indonesian perspective of Realistic Mathematics Education (RME).

In their study, Boyer and Levine (2012) proposed that the students' formal mathematics understanding about proportion can be enhanced by instruction which builds on their early intuitive understanding of proportional relations. Furthermore, the Math Learning Study Committee as cited in CPRE, CAMS and El Paso believe that teaching the cross multiplication before the students understand the proportional relationship is meaningless. It means that the students should understand the proportional relationship before they get the formal lesson of proportion. Hence, the design was implemented in Grade 4 (9-10 years old) as the preparation before they learn the proportion more formally in Grade 5 .

We believe that the students in Grade 4 may have an intuitive understanding of proportionality because they have learned about multiplication and division since the previous grade (Depdiknas, 2006) and they may experience the "proportionality things" in their daily life. The aim of the present study is to know how far the students' intuitive understanding may help them to deal with the comparison problem. Within a design research, we formulated the research question for this study as "How do the 4th Graders using their intuitive understanding about proportion to solve the comparison problem?"

\section{Theoretical Framework}

\subsection{Proportion}

Karplus, Pulos, and Stage (1983); Langrall and Swafford (2000); Silvestre and da Ponte (2012); and Tournaire and Pulos (1985) defined proportion as the equality of two ratios, for example $a / b=c / d$. They also added that in general the proportional problems are categorized as the missing value problem and comparison problem. Missing value problems ask for the fourth number by presenting the three numbers, such as how many candies do we get for Rp10 000 if we know that 5 candies cost Rp2000. Comparison problems present two or more pairs of numbers and ask about their comparison. For instance, we are asked to determine which of two different sodas, soda A and B, is the cheaper one. If it is known that soda A costs Rp4000 for 3 cans while soda B costs Rp3000 for 2 cans, we can say that soda A is cheaper than soda B. According to a review of the literature by Tournaire and Pulos (1985), comparison problems are more difficult than missing value problems. They said that "comparing ratios is an advanced method and the ability to choose the arithmetically easier comparison is acquired long after the proportional techniques are mastered". They also stated that there are two factors from the proportional problem that may influence the students' performance, namely

The structure of the problems, including:

(1) The number structure of the proportion problems influences the subjects' performance. There are three main difficulties: presence of an integer ratio, numerical complexity, and the order of numbers that one is looking for. The presence of integer ratios makes a problem easier. The difficulty introduced by non-integer ratios is widely recognized.

(2) Among problem with units, those with ratios 1:2 are the easiest.

(3) Comparison problems which have equal ratios are easier than those with unequal ratios.

The context used in the problems, including:

(1) The familiarity of the context. A familiar problem is easier than an unfamiliar one.

(2) The presence of a mixture problem. The problem with the context of mixture is more difficult than other contexts for the proportional problems.

(3) People can more easily visualize discrete content than continuous content.

(4) The mode of delivery of the problem.

\subsection{Proportional Reasoning}

Karplus et al. (1983) defined proportional reasoning as a term that denotes reasoning in a system of two variables between which a linear functional relationship exists. According to Langrall and Swafford (2000), proportional reasoning is an important ability to build a foundation for high school mathematics and algebraic reasoning. Furthermore, Kilpatrick, Swafford and Findell; Lamon; Lesh, Post and Behr in Parish (2010), consider the proportional reasoning as a "capstone" of elementary school mathematics. It is necessary to learn the important topics in mathematics such as fraction equivalence, place value, long division, percentage calculation, 
measurement conversions, and derivation of rates which are troublesome for the students.

As pointed out by Boyer and Levine (2012), the development of mathematical understanding is not characterized by "all or none" but is moving from partial to more complete and become less contextually dependent, considering the value and the effectiveness of intuitive capacities. The intuitive understandings influence the people's mathematical skills even after they have internalized the formal mathematics. In line with that, giving the instruction that builds on the students' intuitive understanding of proportional relations may support the development of their proportional thinking.

\subsection{The Curriculum in Indonesia}

Based on the curriculum in Indonesia, the topic of proportion is given in Grade 5 until Grade 8. The standard and basic competence of the proportion which is taught integrated with the fraction during the second semester in grade 5 is described in Table 1.

Table 1. Mathematics curriculum for grade 5 (Depdiknas, 2006)

\begin{tabular}{ll}
\hline Standard Competence & Basic Competence \\
\hline Numbers & \\
5. Using the fractions to solve problems & 5.1 Converting fractions into decimals and vice versa. \\
& 5.2 Adding and subtracting fractions and decimals. \\
& 5.3 Multiplying and dividing fractions and decimals. \\
& 5.4 Using fractions in solving proportional problems \\
& and scale. \\
\hline
\end{tabular}

Considering the mathematics curriculum, we can see that the topic of fraction is also given in grade 4 (as shown in Table 2). Although the problems in basic competence of "solving the problems which involves fraction" usually only involved the operations in the fraction, we can expand it to the simple proportional problem. It means that we can teach the topic of proportion which integrated with the fraction as in grade 5. Accordingly, teaching proportion in grade 4 is reasonable and reliable.

Table 2. Mathematics curriculum for grade 4 (Depdiknas, 2006)

\begin{tabular}{ll}
\hline Standard Competence & Basic Competence \\
\hline Numbers & \\
5. Using the fractions to solve problems & $\begin{array}{c}5.1 \text { Explaining the meaning of fractions and their } \\
\text { order }\end{array}$ \\
& $\begin{array}{l}\text { 5.2 Simplifying fractions } \\
\text { 5.3 Adding fractions } \\
\text { 5.4 Subtracting fractions } \\
\text { 5.5 Solving problems which involves fractions }\end{array}$
\end{tabular}

\section{Method}

\subsection{The Participants}

The aim of this study is to investigate how the 4th Graders use their intuitive understanding about proportion to solve proportional problems. In line with the aim of this study, we invited the students in Grade 4 who still did not get the lesson about proportion.

The participants were 35 fourth-grade students of a public elementary school in Palembang, Indonesia. Six students participated during the pilot experiment to try out the problems that were used in the pretest in order to adjust the sentence and the numbers of the problems. The other 29 students participated in the class teaching experiment. The group of 29 students and the group of six students were from the same school but from different classes. 


\subsection{Research Design}

This study is a part of a design research project on developing the students' proportional reasoning in Grade 4 by using a ratio table as the model. We chose PMRI as an approach to design the problems and the activities that were used in the whole project.

As the preliminary stage, we tried out the problems on six students to find out whether the sentences of the problems were understandable. We also used the students' work from this trial to make some adjustment to the numbers used in the problems.

A week before the teaching experiment began; the 29 students did the pretest and more than half of the class was interviewed. During the interview, the students were asked to explain their answer. They were asked to give their argument about their judgment and explain how they came to their answer.

The students' works from the pretest, the interview with the teacher and the transcript of clinical interviews were used as the data collection. The clinical interview was used as one of the methods to collect the data in this study because it has two main advantages which support the aim of this study. First, it is allowed to make interventions in order to encourage the students to elaborate on their statement. Second, the clinical interview also provides a continual interaction between inference and observation (Opper, Cobb as cited in Singh, 2000).

\subsection{The Problems}

The pretest consists of three problems. The first problem aims to test the students' ability in arithmetic operation. The second problem is a missing value problem. The students were asked to find the number of donuts in 4 boxes if it was known that there were 24 donuts in 2 boxes. The context is familiar for the students, the numbers used in this problem are relatively small and the bigger number is required as the answer. As cited in Tourniaire (1986), Rupley stated that the easier problems for students are the problems with small, integer ratios and questions about what is the biggest number that can be found.

However, according to the aims in this study which want to determine how the students of grade 4 deal with the comparison problem we only focus on the third problem, which asked about the comparison of the price. It may be more difficult for the students than the second problem because to solve this problem we have to compute a new set of numbers for each situation, and we have to find out which proportions will give a good comparison situation. On this problem, the students were asked to determine the cheaper apples between two minimarkets, A and B. The apple in minimarket A costs Rp50 000 per $2 \mathrm{~kg}$ and the apple in minimarket B costs Rp60 000 for 3 $\mathrm{kg}$. The context in this problem is also familiar for the students. They experience it in their daily life.

3. Manakah yang lebih murah, harga apel di minimarket $A$ atau minimarket $B$ ? Jelaskan alasanmu!
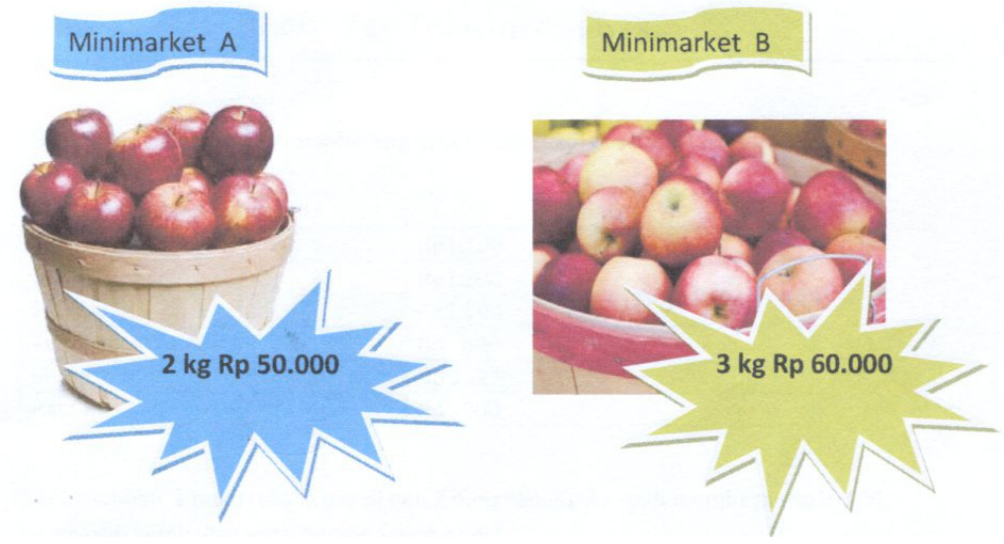

Figure 1. The third problem

Translation: Which one is cheaper, the apples in minimarket A or minimarket B? Give your reason!

\section{Results}

Based on the students' works, there were 19 of 29 students who gave the correct answers and only 11 of them who could give the sufficient reason and arguments. The majority of them compared the price of $1 \mathrm{~kg}$ apple in 
minimarket A and the price of $1 \mathrm{~kg}$ apple in minimarket $\mathrm{B}$. They might come to the idea of proportionality in a simple way that was we should compare the price of two different things in the same amount. Thus, they were able to apply the concept of division in this situation.
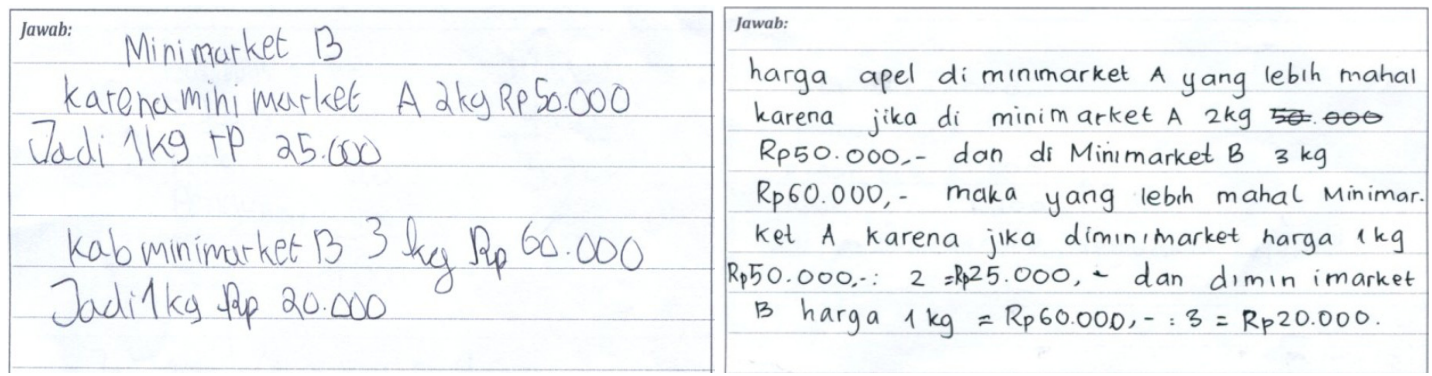

Figure 2. Rizky’s answer (left) and Ghifara's answer (right)

\section{Translation:}

(Rizky's answer-left): minimarket B (has the cheaper price) because minimarket A $2 \mathrm{~kg}$ cost Rp50 000. So $1 \mathrm{~kg}$ is Rp25 000. Meanwhile, in minimarket B $3 \mathrm{~kg}$ cost Rp60 000, so $1 \mathrm{~kg}$ is Rp20 000.

(Ghifara's answer-right): The price of apple in minimarket A is more expensive because at minimarket A $2 \mathrm{~kg}$ Rp50 000 and minimarket B $3 \mathrm{~kg}$ Rp60 000. Then the more expensive (apples) is in minimarket A because at minimarket A, the price of $1 \mathrm{~kg}$ apple is Rp50 $000: 2=\mathrm{Rp} 25000$ and at minimarket $\mathrm{B}$, the price of $1 \mathrm{~kg}$ apple is Rp60 000: 3= Rp20 000 .

Meanwhile, the other students considered the absolute value of the price to determine the cheaper apples. They could not think the relation between the price and the weight. They might not realize that the price and the weight altogether influenced the comparison situation. There were also some students who considered both the price and the weight but did not compare it in the right way.

Later, we discuss five students' work and their interview in more depth. We chose these five students as the representative of different students' answers.

\subsection{Lulut}

One of the students who concerned on the absolute value to solve the comparison problem was Lulut. It seems reasonable when she did not use the proportionality in a comparison situation because she could not solve the simple proportional problem (Lulut used addition in a wrong way to solve problem 2). It is common that a student, who cannot solve the simple missing value problem, has difficulties to solve more complex problems which require more complex proportional situation.

She answered that the price of apples in minimarket A was cheaper than the price of apples in minimarket B. She did not write the clear reason (see Figure 3).

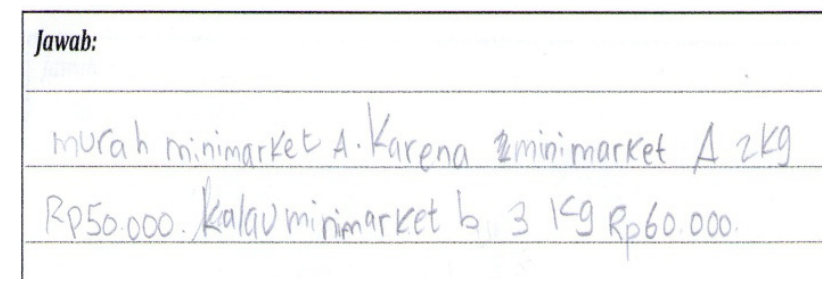

Figure 3. Lulut's answer

Translation: Minimarket A is cheaper. Because in minimarket A, $2 \mathrm{~kg}$ costs Rp50 000 while in minimarket B 3 kg costs Rp60 000.s

During the interview in the following week after the pretest, Lulut also gave the same answer for the same 
question. She believed that the price of apples in minimarket A was cheaper than the price in minimarket B. When the researcher asked her why she considered the price of apples in minimarket $\mathrm{A}$ as the cheaper one, she answered that 60000 was 10000 more than 50000 . She just considered the price at first.

Later, the conversation was developed to an idea that the weight also determined the cheaper price. She considered the weight of apples but in different way. She knew that the price of the heavier apple was more expensive then she came to the conclusion that the heavier weight was more expensive and vice versa. According to her answer, it seems that she did not consider the idea of proportionality in comparison situation. She just considered the absolute value in this problem by seeing the price. She could not make a relation between the price and the weight; both to build up the comparison situation.

To build up the idea of relation between the price and the weight, the researcher changed the numbers on the problem. First, the question was changed as the price of apples in minimarket A is Rp50 000 for $2 \mathrm{~kg}$ while in minimarket B is Rp50 000 for $3 \mathrm{~kg}$. In this problem, the prices were the same but the weight was different. We intended to see whether Lulut could reach the idea that for the same price, the apples that the heavier weight means the cheaper one. In fact, she could determine that the price of apples in minimarket B was cheaper than in minimarket A. There was no more explanation about how she could come to that thinking. Maybe, she could give the correct answer not because she applied some mathematics strategy, such as the unit method (look for the price per $\mathrm{kg}$ ). It is possible that she only answered based on her experience in real situation; if we buy something with the same price and get more, it means cheaper.

Second, the researcher changed the problem as the price of apples in minimarket A was Rp50 000 for $2 \mathrm{~kg}$ while in minimarket B was Rp60 000 for $2 \mathrm{~kg}$. The weight was the same and the prices were different. We expected that the students might realize the relation between the price and the weight. Then she might grasp an idea about how to create a good proportion to compare the prices. For this problem, she also gave the right answer; she said that the price of apples in minimarket A is cheaper. Lulut also did not give any reason how she could come to that conclusion. It may indicate that the real situation according her experience lead her to the conclusion and not because of mathematical reason.

Actually, the final goal was to guide her into comparison of the prices for $6 \mathrm{~kg}$ apples in minimarket A and minimarket B. To bring her about the idea of which proportion can give a good comparison, the interview was continued with the discussion to determine the price of $4 \mathrm{~kg}$ apples in minimarket A. We hoped that, through working on this, she might generalize the idea that we need to make the equal number of weight from both apples before she compared the price. However, Lulut could not go further. She was struggling to find the price of $4 \mathrm{~kg}$ apples in minimarket A.

Dealing with the idea that proposing a proportional question which uses 1 as the unit may lead the students to gain the idea of repeated addition, the researcher gave the similar problem with 1 as the unit, such as "The price of 1 ballpoint is Rp1000, how much is for 2 ballpoints?" and "The price of 1 ballpoint is Rp2000, how much the price for 2 ballpoints?" Here, she could do the repeated addition to find the right answer. When back to the original problem, she did a mistake. She added the 50000 for 4 times as it was a price for a kilogram of apples. Although in the end she could find the price for $4 \mathrm{~kg}$ and $6 \mathrm{~kg}$ apples in minimarket $\mathrm{A}$, it seems that she still had difficulties in connecting the numbers of weight and the price if it was not in unit of 1 .

It seems that Lulut needed more time to develop the idea of repeated addition because, so far, she only did well on the problem with 1 as the unit. It might because the concept of multiplication, which was also a repeated addition, was not really developed well in her mind.

\subsection{Nafisah}

Nafisah had the same tought as Lulut that the heavier the weight, the more expensive the price was. 


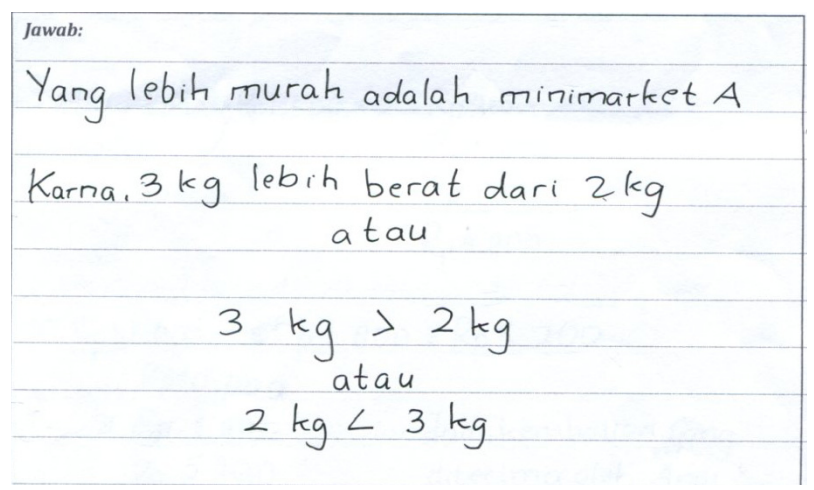

Figure 4. Nafisah's answer

Translation: In minimarket A, (apple) is cheaper because $3 \mathrm{~kg}$ is heavier than $2 \mathrm{~kg} .3 \mathrm{~kg}>2 \mathrm{~kg}$ or $2 \mathrm{~kg}<3 \mathrm{~kg}$.

In the interview session, Nafisah also gave the same answer. She said that the price of apples was cheaper in minimarket $\mathrm{A}$. When the researcher asked her reason, she said that $2 \mathrm{~kg}$ was lighter than $3 \mathrm{~kg}$. Maybe, in her mind the word cheaper just meant that we spent less money without paying attention to the amount of apple that we got.

Then the researcher asked some questions to follow up.

Researcher: If in minimarket A, $2 \mathrm{~kg}$ of apples is Rp50 000 and in minimarket B, $1 \mathrm{~kg}$ of apples is Rp60 000 . Which is the cheaper one?

Nafisah pointed out minimarket A.

Researcher: But you said that the lighter one is the cheaper.

Nafisah: It depends on the price.

From the conversation above, we can see that Nafisah understood that the lighter weight was not always cheaper. Here, she considered the price.

Then the discussion was continued with some missing values questions before bringing the idea of comparing the price for the same number of weight. The researcher expected that she would not have any difficulties to find the price of a number of $\mathrm{kg}$ apples because she could answer the second problem on the pretest, which was a missing value.

Researcher: Now, how much is $6 \mathrm{~kg}$ of apples in minimarket $A$ ?

Nafisah: Rp120 000.

Researcher: How you know that?

Nafisah: 6 times 2.

It was quite surprising that she looked for the price of $6 \mathrm{~kg}$ apples by multiplying the $6 \mathrm{~kg}$ with 2 (from $2 \mathrm{~kg}$ ) and get the price 120000 . To make sure, the researcher changed the number with the simpler one.

Researcher: How much is $4 \mathrm{~kg}$ ?

Nafisah: Rp80 000.

She explained that she got 80000 from 4 times 2 . Then it was the same as her strategy to find the price of $6 \mathrm{~kg}$ apples. It means that Nasifah still did not understand about the proportionality concept in missing value problems. She might just apply the procedure that she got from her previous lesson about multiplication to solve the missing value problem during the pretest. When she chose which number should be multiplied to other, she got confused.

From the discussion with Lulut and Nafisah, we might say that the students should be able to solve the simple proportion first before they start to solve the comparison problem. This finding is in line with the study by Tourniere \& Pulos (1985) which stated that the comparing ratios is an advanced method, the way to choose the easier proportion to do comparison will be acquired after the proportional techniques are mastered.

\subsection{Mutia}

Besides them, there were some students who knew that there was a relation between the price and the weight. 
They might also relate it to the idea of proportion but they did not know how to relate it in the right way.

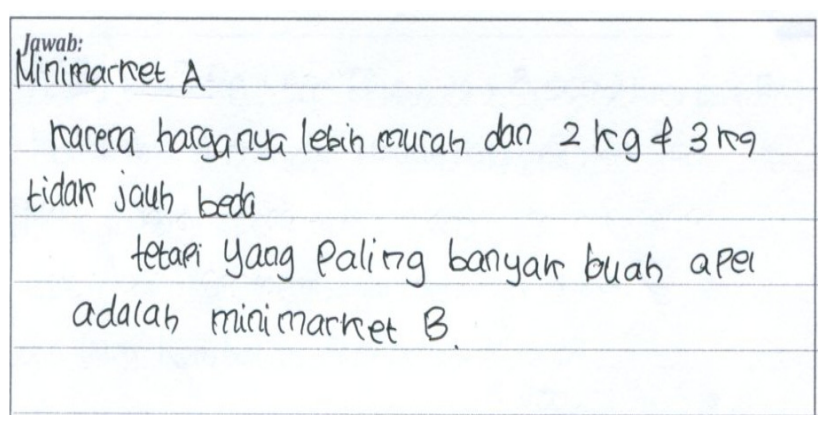

Figure 5. Mutia's answer

Translation: Minimarket A, because the price is cheaper and there is no big difference between $2 \mathrm{~kg}$ and $3 \mathrm{~kg}$. But the biggest number of apples is in minimarket B.

Mutia knew that both the price and the weight influenced the comparison situation. She also tried to compare how big the differences of $1 \mathrm{~kg}$ and its price. But, she did not know how to compare the difference between the weights and the difference of the price in the right way. So, during the interview, the researcher tried to lead her to find a certain strategy to compare those differences.

First, the researcher tried to make her notice that we could not compare the difference of the prices and the difference of the weight just by slightly seeing and just based on the opinion. The researcher changed only the price of the apples in minimarket A. Mutia convinced that the difference of 5000, 2000, 1000, 200 was worthier than $1 \mathrm{~kg}$ apples. She chose to buy the apples in minimarket A than minimarket B. This probably happened because she only noticed about the number that 1 was less than 5000, 2000, 1000 and 200 without any considerations. She did not notice that the difference of $1 \mathrm{~kg}$ from 2 to $3 \mathrm{~kg}$ of apples was more than the difference of Rp10 000 from Rp50 000 to Rp60 000.

However, after the researcher asked whether she was sure that Rp100 is worthy enough to ignore the difference of the weight, she changed her mind. She said that if only Rp100, it was better to buy apples in minimarket B. Until the end, she insisted that minimarket A is cheaper than minimarket B. Although the researcher gave hint to make the equal number of apples before comparing the prices, she did not think about that until the last session of the interview.

\subsection{Salwa}

The other student, Salwa, thought the similar way as Mutia did, but in the other way around. Salwa answered that the price of apples in minimarket B was cheaper than in minimarket A. In her work, she tried to explain in her own words that the difference in price was smaller than the difference in weight. But, it was not clear how she could come to that conclusion.

Although her reason was not sufficient to argue in a comparison situation, it indicated that she noticed the relation between the price and the weight proportionally. It is also possible that she did the estimation between the price and the weight of apples in the both minimarkets. 


Jawab:
Minimarket $A=2 \mathrm{~kg}=R_{p} .50 .000$
Minimarket $B=3 \mathrm{~kg}=R_{p} .60 .000$
$2 \mathrm{~kg}$ lebih kecil dari $30 \mathrm{~kg}$.
Jadi, harga dari antara Minimarket A dan
Minimarket B harganya hanya berda $R_{p}$.
10.000 , sedangkan, $3 \mathrm{~kg}$ itu cukup banyak.
Jadi, yanglebih murah adalah harga apel
di Minimarket B.
Karena hanya berbeda $R_{p} .10 .000$, sedang-
kan, I kg cukup ban yak.

Figure 6. Salwa's answer

Translation: $2 \mathrm{~kg}$ is smaller than $3 \mathrm{~kg}$. The difference of the price between (apples) in minimarket $\mathrm{A}$ and minimarket B is only Rp10 000, while $1 \mathrm{~kg}$ is many. So, the price of apples in minimarket B is cheaper. Because the price difference is just Rp10 000 meanwhile $1 \mathrm{~kg}$ is many.

As we can see on Figure 6, she compared the weight and the price from the apples in the both market. It shows that she had a proportional thinking and did not only consider the absolute value in comparison problem. But, what she did after that was to compare between the difference of the price and the difference of the weight from both apples. It seems reasonable to do that but it is also difficult to do by just a slightly seeing.

During the interview, Salwa used the same reason to explain her answer why the price of apples in minimarket B was cheaper than in minimarket A.

\section{Salwa: 1 kilogram is many and 10000 is a small amount.}

To see how Salwa could be sure that the difference of 10000 was nothing compare to the $1 \mathrm{~kg}$ of apples, the researcher intended to change the numbers on the problem. We wanted to know whether it was just coincidence or she had another reason in her mind but she might have difficulties to express it. Thus, we changed the difference of the weight and the price. The price of apples in minimarket A is Rp100 000 for $4 \mathrm{~kg}$ while in minimarket B is Rp60 000 for $3 \mathrm{~kg}$. For this problem, Salwa came up with the different reason. Suddenly she thought of the unit method and then compared the price for $1 \mathrm{~kg}$ for each apple.

Salwa: 3 divided by 60000 is 20000 and 4 divided by 100000 is 25 000. So, the price for per $\mathrm{kg}$ in minimarket $A$ is 25000 while in minimarket $B$ is 20000 . B is cheaper.

She did mispronounce that 3 divided by 60000 instead of 60000 divided by 3 . However, it did not change the fact that, here, her reason was appropriate for the comparison problem. Based on her last reason, it seems that she already found the way to convince the other by looking the price per $\mathrm{kg}$. It also indicated that the modified problem might encourage the students to look for other ways in convincing the others.

\subsection{Ghafar}

Ghafar was one of the students who gave a right answer without the clear reason or argument. He said that the price of apples in minimarket B was cheaper than the price of apples in minimarket A because the price in minimarket B was only Rp60 000 for $3 \mathrm{~kg}$ of apples. We could not be sure that he really could do the comparison or it was just a coincidence before further investigation.

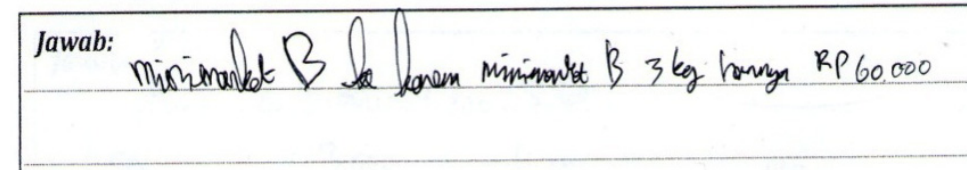

Figure 7. Ghafar's answer 
Translation: Minimarket B because in minimarket B 3 kg just costs Rp60 000

In fact, during the interview which was conducted the following week after the pretest, Ghafar gave different answer from the one he proposed on pretest. He said that the price of apples in minimarket A was cheaper than minimarket B. He determined the cheaper apple by comparing the weight of apple. He believed that the smaller weight meant the cheaper one. He also used the same argument to answer the follow-up questions.

Researcher: If the price in minimarket $A$ is $R p 20000$ for $1 \mathrm{~kg}$ (the price in minimarket $B$ remains the same as the original problem).

Ghafar: Minimarket A, because it is only $1 \mathrm{~kg}$.

Researcher: If the price in minimarket B is Rp30 000 for $1 \mathrm{~kg}$ (the price in minimarket A remains the same as the original).

Ghafar: Minimarket B because it is $1 \mathrm{~kg}$ for Rp30 000 while in minimarket A $2 \mathrm{~kg}$ for Rp50 000.

For the first question in the transcript, the price should be the same. But Ghafar answered that minimarket A was the cheaper one, because he considered that the weight in minimarket A was $1 \mathrm{~kg}$ while in minimarket B $3 \mathrm{~kg}$. It was also the same for the second question in the transcript, he still believed that $1 \mathrm{~kg}$ apple which cost Rp30 000 was cheaper than $2 \mathrm{~kg}$ apples cost Rp50 000. Then, the researcher made the problem with the same price but different weight, Rp50 000 for $2 \mathrm{~kg}$ apples in minimarket A and $3 \mathrm{~kg}$ apples in minimarket B. The aim of this question was to make him realized that he could not only consider the weight to determine the cheaper apples. For the first, he answered the price was the same, because both of them cost Rp50 000, but when the researcher remarked that the weight was different, Ghafar changed his answer. He realized that the price of apples in minimarket B was cheaper. Then, he did not assume that the smaller weight as the cheaper one anymore.

The next question was about the situation in which the apples had the same weight but different price. The price of apples in minimarket B was changed into Rp40 000 and the price in minimarket A remained the same. For this question, Ghafar was able to see that the price in minimarket B was cheaper than minimarket A.

Through the discussion, Ghafar had a conclusion as follow. If the price was the same, then we could determine which one was the cheaper. It was by comparing the weight. The heavier weight was cheaper. If the weight was the same then we could see the price to determine which one was cheaper.

Although in the end, he could not solve the original problem, we might say that the context here has a big role to lead the students to think further. Because of the context familiar for the students, the students may relate the problem to their own experience. Thus, the students may be able to construct their own idea to solve the problem.

Based on the discussion with Ghafar, we can say that proposing the same problem with different price and weight can help the students to consider both the price and weight at the same time to do comparison. We can propose the problems which have price difference but have the same weight and have different weight but the same price. However, it needs further discussion to be able to compare particular objects with different price and different weight. The students need to do more exploration to relate the two sets of numbers and make the comparison between them.

\section{Conclusion}

Based on the analysis of the data collection, we may conclude that the students have different levels of intuitive understanding about proportion. The students who could not solve simple proportional problem (missing value) could not work on comparison problem, which contains more than one set of numbers. Even the ones who can solve the proportional problem may still have difficulties to deal with the comparison problem. With this consideration, we may say that the students should be able to solve the simple proportional problem before they start to solve the comparison problem. Therefore, in a learning sequence, the comparison situation should be given after the missing value problem.

The students' experiences also influence the students' response to the proportional problem. Sometimes, in a simple comparison, their familiarity to the context may lead them to see the proportionality aspect in comparison problem. Of course, the students' experience is not enough to build the mathematics concept of proportion. They need to learn more to develop their proportional reasoning. However, we can use their experience as the starting point to build the understanding of proportionality. Posing the similar problems with the different numbers may encourage the students to find different idea; the number chosen will affect the students' response. Sometimes we need to propose the smaller number to help the students find the strategy before they can implement it into the original problem, but at the other time we need to propose the bigger number to encourage them to develop the 
existing idea.

There is a different starting point from the different levels of students' ability. Although this study was only conducted with a few participants, it described how the different levels of students' ability influenced the treatment that should be given to the students, such as the different types of question that may support them to develop their thinking. It is not easy for a teacher to facilitate all the students' needs by giving an individual coach for every student in the class. Thus, we need lessons with a lot of discussions among the students, comparing their different ways of reasoning, discussing different approaches in order to support them in developing their proportional reasoning.

As aforementioned, the present study was part of the larger study, in which a learning and teaching trajectory were tested. Within the learning design we also developed a teacher guide that may help the teacher in facilitating the students to develop their proportional reasoning. The findings from the present study contribute to the development of the learning trajectory and the teacher guide in the larger study.

\section{Acknowledgements}

The authors would like to appreciate Ms Intan and her students for their participations in this study. Secondly, we also would like to extend the gratitude to Mark Uwland, Retno Widyowati, Ade Wira Sanjaya and Ida Machdarifah for correcting some of the English in this article. Lastly, we would like to say thank you to the Dikti Dekdikbud Indonesia (Indonesian Ministry of Higher Education) who funded this study within the IMPoME (International Master Program on Mathematics Education) which collaborated with Sriwijaya University, Indonesia and Utrecht University, the Netherlands.

\section{References}

Boyer, T. W., \& Levine, S. C. (2012). Child proportional scaling: Is $1 / 3=2 / 6=3 / 9=4 / 12$ ? Journal of Experimental Child Psychology, 111(2012), 516-533. http://dx.doi.org/10.1016/j.jecp.2011.11.001

CPRE, CAMS, \& El Paso. (not mentioned). Proportional reasoning: Student misconceptions and strategies for teaching. PCK Tools. Consortium for Policy Research in Education (CPRE), Consortium for Achievement in Mathematics and Science (CAMS) \& El Paso. Retrieved from http://www.epcae.org/uploads/documents/Proportional_Sept\%2020.pdf

Depdiknas. (2006). Kurikulum Tingkat Satuan Pendidikan Sekolah Dasar. Jakarta: Depdiknas.

Karplus, R., Pulos, S., \& Stage, E. K. (1983). Early adolescents' proportional reasoning on 'rate' problems. Educational Studies in Mathematics, 14, 219-233. http://dx.doi.org/10.1007/BF00410539

Langrall, C. W., \& Swafford, J. (2000). Three Balloons for Two Dollars: Developing Proportional Reasoning. Mathematics teaching in the middle school, 6(4), 254-261. Retrieved from http://math.buffalostate.edu/ wilsondc/MED\%20308/ProportionalThinkingMTMS.pdf

Parish, L. (2010). Facilitating the Development of Proportional Reasoning through Teaching Ratio. In L. Sparrow, B. Kissane, \& C. Hurst (Eds.), Shaping the future of mathematics education: Proceeding of the 33rd annual conference of the Mathematics Education Research Group of Australasia. Fremantle: MERGA.

Silvestre, A. I., \& da Ponte J. P. (2012). Missing value and comparison problems: What pupils know before the teaching of proportion. $P N A, \quad 6(3), \quad 73-83 . \quad$ Retrieved from http://digibug.ugr.es/bitstream/10481/19500/1/120201Art\%C3\%ADculoSilvestre\%26Ponte.pdf

Singh, P. (2000). Understanding the concepts of proportion and ratio constructed by two grade six students. Educational Studies in Mathematics, 43, 271-292. http://dx.doi.org/10.1023/A:1011976904850

Tourniaire, F., \& Pulos, S. (1985). Proportional reasoning: A review of the literature. Educational studies in Mathematics, 16, 181-204. http://dx.doi.org/10.1007/BF02400937

Tourniaire, F. (1986). Proportion in elementary school. Educational Studies in Mathematics, 17, 401-412. http://dx.doi.org/10.1007/BF00311327

Van Galen, F., Feijs, E., Figueiredo, N., Gravemeijer, K., Herpen, E., \& Keijzer, R. (2008). Fractions, Percentages, Decimals, and Proportions: A Learning-Teaching Trajectory for Grade 4, 5 and 6. The Netherlands: Sense Publisher.

Van Galen, F., \& van Eerde, D. (2013). Solving Problem with the Percentage Bar. IndoMS. Journal on Mathematics Education, 4(1), 4-8. Retrieved from http://jims-b.org/

Zulkardi, Z. (2002). Developing A Learning Environment on Realistic Mathematics Education for Indonesian 
Student Teacher (Doctoral Dissertation, University of Twente).

\section{Copyrights}

Copyright for this article is retained by the author(s), with first publication rights granted to the journal.

This is an open-access article distributed under the terms and conditions of the Creative Commons Attribution license (http://creativecommons.org/licenses/by/3.0/). 